\title{
Effects of light source and intensity on sexual maturation, growth and swimming behaviour of Atlantic salmon in sea cages
}

\author{
Tom Johnny Hansen*, Per Gunnar Fjelldal, Ole Folkedal, Tone Vågseth, \\ Frode Oppedal
}

Institute of Marine Research, 5984 Matredal, Norway

\begin{abstract}
We investigated how highly efficient LED light sources may be used in Atlantic salmon cage farming. Specifically, we tested the incidence of sexual maturation and growth patterns in autumn sea-transferred Atlantic salmon Salmo salar L. during their second sea winter given continuous artificial light (LL) (between 13 January and 18 June) of 5 different intensities using LED sources, compared to a single intensity provided by a metal halide (MH) source or a control treatment of natural light (NL). Growth effects were independent of light source, but increased with irradiance. We propose a model wherein sufficiently high irradiance from the artificial light source will give a long day signal throughout late winter and spring, an intermediate irradiation will give a long day signal until it is outcompeted by the seasonal increase in natural light, and an irradiance that is always below the threshold will not be perceived as different from natural light. Sexual maturation in males (6.1\% under NL) was evenly arrested at all intensities, and swimming activity at night increased during winter in lit groups. We conclude that LED lamps may replace MH sources at similar intensity. Reducing the light irradiance of the superimposed light reduced the growth-stimulating effect, but all irradiances reduced the incidence of sexual maturation.
\end{abstract}

KEY WORDS: Salmo salar $\cdot$ Photoperiod $\cdot$ Salmonid aquaculture $\cdot$ Cage environment

\section{INTRODUCTION}

In the late 1980s and early 1990s, experimental studies demonstrated the potential of using artificial light as a method for reducing the incidence of unwanted sexual maturation (Taranger et al. 1995, Oppedal et al. 1997) and increasing growth rate (Saunders \& Harmon 1988, Kråkenes et al. 1991, Hansen et al. 1992) in cage-farmed Atlantic salmon Salmo salar. The commonly adopted protocol has been to use continuous artificial light between early January and June (Leclercq et al. 2011). This protocol reduces the incidence of sexual maturation (see review by Taranger et al. 2010) and stimulates somatic growth (e.g. Hansen et al. 1992, Oppedal et al. 1997, 2006). The continuous light treatment be-

*Corresponding author: tomh@imr.no tween January and June is an advancing photoperiod (e.g. Taranger et al. 2010), which phaseadvances endogenous rhythms (Duston \& Bromage 1988, Bromage et al. 2001) and reduces the incidence of sexual maturation by advancing and shortening a critical time window (gate) during which puberty commences (Duston \& Bromage 1988, Taranger et al. 2010). It can also advance a seasonal growth pattern (Oppedal et al. 1999, 2006, Endal et al. 2000, Nordgarden et al. 2003) and/or affect growth by direct photo-stimulation (Saunders \& Harmon 1988, Komourdjian et al. 1989, Björnsson et al. 1997). Light also affects both vertical distribution and swimming behaviour (Oppedal et al. 2001).

In most of the studies cited above, relatively high intensity, wide spectrum, metal halide lamps were

(C) The authors 2017. Open Access under Creative Commons by Attribution Licence. Use, distribution and reproduction are unrestricted. Authors and original publication must be credited. 
used, but these powerful lamps have a high running cost (Leclercq et al. 2011) and potential welfare impacts (Migaud et al. 2007). In earlier studies on Atlantic salmon (Oppedal et al. 1997, 1999) and rainbow trout Oncorhynchus mykiss (Taylor et al. 2006), where continuous light was superimposed on the natural light in cages or tanks, the growth response was dependent on the light intensity/irradiance of the superimposed light. Vice versa, Leclercq et al. (2011) found a linear relationship between maturation rate and mean light-irradiance (from light sources giving different light spectra) in the rearing volume, but their study could not characterize the effect of light intensity on growth.

Following the success of cage illumination, specially designed underwater lighting systems have been developed. Some of these are built from light-emitting diodes (LEDs), and have a long lifespan without a weakened output effect, high electrical efficiency, come to full brightness without the need for a warmup time, can be built to emit specific light distributions and can be dimmed down to a desired irradiance.

The aim of the present study was to compare the growth, incidence of sexual maturation and swimming speed of 2-sea winter (2SW) autumn-transferred Atlantic salmon reared under continuous light (LL) of 5 different intensities using a specially designed LED lamp compared to 1 intensity using a metal halide $(\mathrm{MH})$ source and a control treatment of natural light (NL).

\section{MATERIALS AND METHODS}

The experiment was carried out at the Institute of Marine Research sea cage facilities at Matre in Masfjorden, Norway $\left(60.8^{\circ} \mathrm{N}\right)$, from 13 January to 18 June 2012. About 40000 Atlantic salmon (mean \pm SD: $3.3 \pm 0.9 \mathrm{~kg}$ ) were pumped into a well-boat and randomly re-distributed into 13 experimental cages. We used 2SW fish to increase the potential for sexual maturation. Each cage was $12 \mathrm{~m}$ long $\times 12 \mathrm{~m}$ wide $\times$ $12 \mathrm{~m}$ deep $\left(1728 \mathrm{~m}^{3}\right)$ and was stocked with approximately 3077 individuals. These fish were produced from eyed eggs (Aqua Gen AS, Trondheim, Norway) incubated on 13 January 2010, first fed under continuous light from 16 March 2010 and reared under a $6 \mathrm{wk}$ light:dark 12:12 h photoperiod followed by $6 \mathrm{wk}$ under continuous light before being transferred to seawater as underyearling smolts $(84 \pm 12 \mathrm{~g})$ on 22 October 2010. The fish were reared in 4 cages under natural photoperiod until the start of the experiment on 13 January 2012.

\section{Experimental design}

An overview of the experimental farm with placement of the treatment groups is shown in Fig. 1. Three cages were exposed to NL and 10 cages to continuous additional light (LL). The lamps were positioned centrally within the cage, at $7 \mathrm{~m}$ depth from January and moved to $5 \mathrm{~m}$ depth in early April. These depths were chosen to match the preferred temperature and swimming depth of the fish (Oppedal et al. 2007), which were confirmed using echo-sounders continuously displaying vertical distribution (Oppedal et al. 2011). Three of the LL cages were illuminated by 1 submersed MH lamp of $400 \mathrm{~W}$ (Sublite 400W Integra, Akvagroup), and 7 cages were illuminated by custom-made dimmable LED lamps (modified SubLED400W, Akvagroup) with maximum power rating of $400 \mathrm{~W}$. The LED lamps were built from selected individual LEDs (neutral

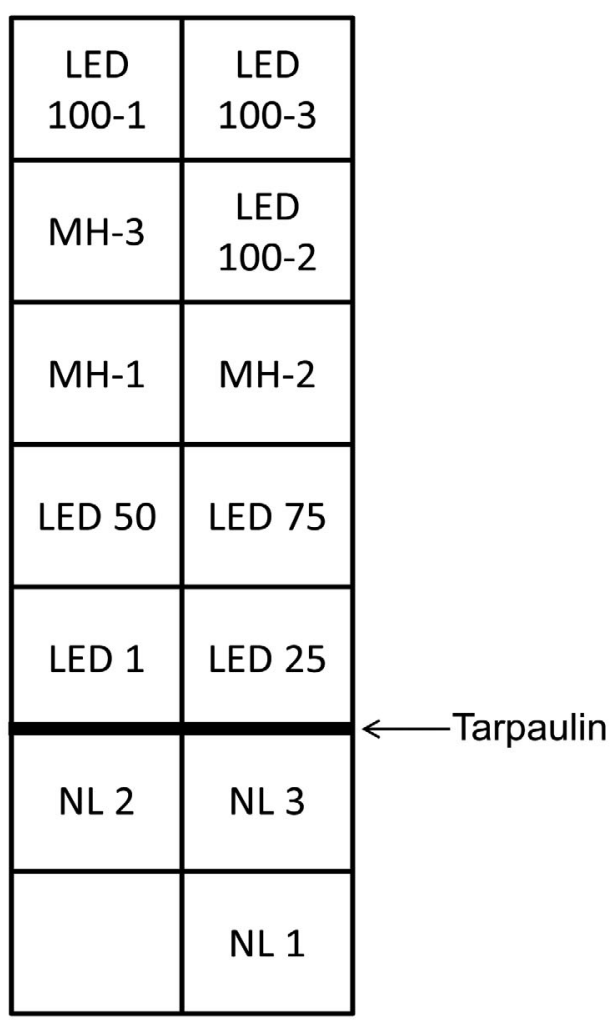

Fig. 1. Overview of the experimental farm with the placement of the different experimental cages. Three cages were illuminated by natural light (NL), 3 by submersed $400 \mathrm{~W}$ metal halide $(\mathrm{MH})$ lamps and 7 by light-emitting diode (LED) lamps. Three of the LED-lit cages were illuminated with the LED sources at their maximum output (100\%), with the remaining 4 LED lamps dimmed down to 75, 50, 25 and $1 \%$ (minimum setting possible). See 'Materials and methods' for more details 
white, royal blue, blue and cyan) to generate a normal light distribution with slightly more energy in the blue-green colour spectrum (Fig. 2). Three of the LED-lit cages were illuminated with the LED sources at their maximum output $(100 \%)$, with the remaining 4 LED lamps dimmed down to $75,50,25$ and $1 \%$ (minimum setting possible). Measured light irradiances $0.5 \mathrm{~m}$ from light sources at the start of the trial in decreasing order were: $3.8,3.3,2.3,1.13$ and $0.06 \mu \mathrm{mol} \mathrm{s}^{-1} \mathrm{~m}^{-2}$ for LED lamps and $4.5 \mu \mathrm{mol} \mathrm{s}{ }^{-1}$ $\mathrm{m}^{-2}$ for MH lamps. Six tarpaulins $(5 \mathrm{~m}$ wide $\times 10 \mathrm{~m}$ deep) were mounted between control cages and lit cages to minimize stray lighting. Each tarpaulin overlapped the neighbouring tarpaulin by $1 \mathrm{~m}$. Group placement in cages was chosen to keep the highest intensities away from low intensity and control groups (Fig. 1). The 3 replicates of both LED and metal halide treatment were randomly allocated. The fish were fed commercial dry feed (Optiline 2500-9, Skretting) in excess twice daily (between 08:00 and 10:00 $\mathrm{h}$ and between 13:00 and 15:00 h). Due to technical problems with the light and feeding system, 1 replicate LED cage (LED 100-3) was removed from all analysis.

Dead fish were removed from the cages every day. Mortality was low $(<0.7 \%)$ during the study and was not related to treatment.

\section{Sampling}

On 16 January, 13 April and 18 June, approximately 100 fish from each cage were sampled. Consequently the study involved 3 samples and 2 periods (first period between 16 January and 13 April and last period between 13 April and 18 June). Fish were sampled with a casting net $(5 \times 5 \times 7 \mathrm{~m})$ which was deployed at the cage bottom for 15 to $25 \mathrm{~min}$, after which it was rapidly pulled to the surface. From this sample (300-1000 individuals), subsamples of 10 to 50 fish were netted out using a crane-operated, $1 \mathrm{~m}$ diameter circular net. In January and April, the fish were anaesthetised (Finquel®, $100 \mathrm{mg} \mathrm{l}^{-1}$ ), weighed to the nearest $10 \mathrm{~g}$, fork length measured to the nearest $\mathrm{cm}$ and returned to the cage. In June, the fish were killed with a blow to the head followed by bleeding, measurements were taken, and the fish were opened, sex determined and the gonads weighed. Males with a gonadosomatic index (GSI) > $0.4 \%$ (e.g. Endal et al. 2000) and females with a GSI $>0.5 \%$ were considered to have started their sexual maturation.

\section{Swimming speed}

Cameras were positioned at the depth of the main school to describe representative swimming speed by observing NL, MH and LED at $100 \%$ output (LED100) cages on 1 random day/night within each period (17/21 February, 27/29 March and 31 May). Instantaneous swimming speeds were calculated in body lengths (BL) $\mathrm{s}^{-1}$ by recording the time taken between the snout and the tail of a fish passing a vertical reference. Perpendicular to the main current direction, a random sample of 10 fish was observed in both directions to account for potential effects of water current speed. Observations within the dark cages at night were aided by use of an infra-red light source (see Korsøen at al. 2009).
Fig. 2. Spectral distribution of the light emitted by the LED and metal halide lamps. The LED lamps were built from selected individual LEDs (neutral white, royal blue, blue and cyan) to generate a normal light distribution with slightly more energy in the blue-green colour spectrum

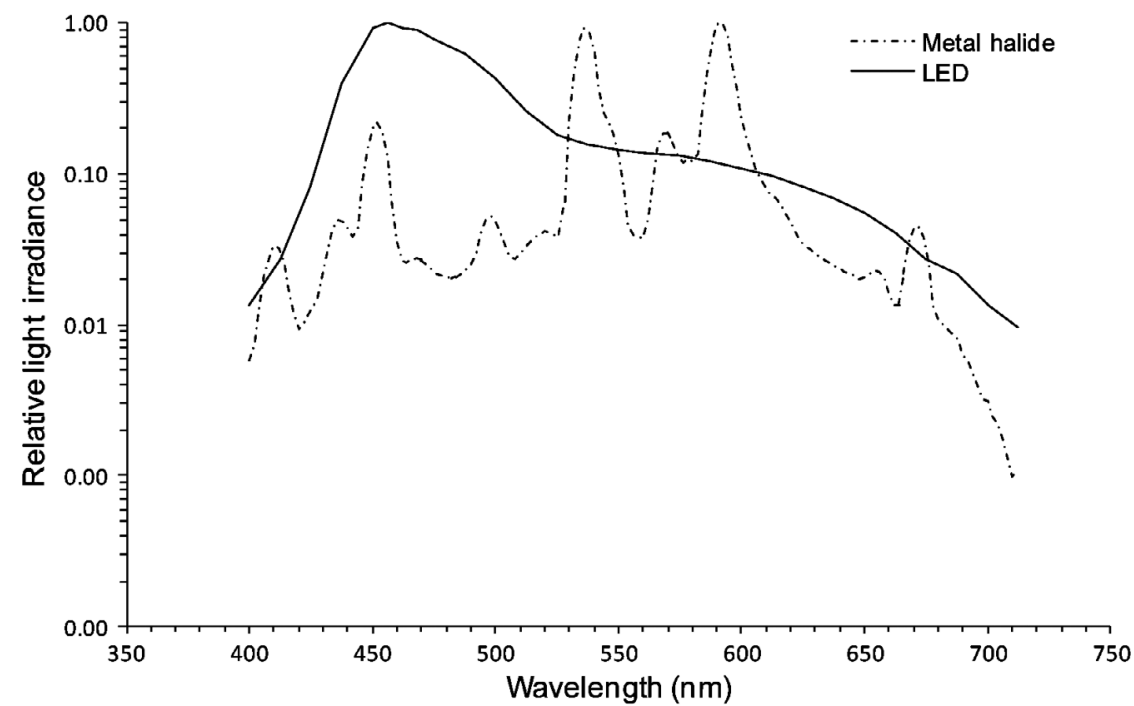




\section{Light spectral composition and intensity}

The spectral irradiance of the 2 lamps over the visible spectrum ( $\lambda$ 400-740 nm; Fig. 2) was measured $0.5 \mathrm{~m}$ from the light source within a tank of saltwater using a spectrophotometer (RAMSES-ACC.VIS hyperspectral UV-VIS, TriOS) in a dark room. At their full output, both the MH and LED lamps gave measureable irradiance between 400 and $715 \mathrm{~nm}$. However, a broad peak of the LED lamp was evident between 425 and $525 \mathrm{~nm}$ (blue and green area). The $\mathrm{MH}$ lamp had several narrow-banded peaks, at $592 \mathrm{~nm}$ (orange), 536 (green/yellow), 452 (violet/ blue) and $570 \mathrm{~nm}$ (yellow).

At the farm, measurements were carried out using a LI-193SA spherical quantum sensor (LI-COR) with a sensitivity down to $0.01 \mu \mathrm{mol} \mathrm{s} \mathrm{m}^{-1} \mathrm{~m}^{-2}$ and a LI1400 logger unit. NL daytime measurements were done on 21 February at 13:00 h with no cloud cover, with snow on the mountains, but with no direct sunlight at the farm. Measurements started at $0.1 \mathrm{~m}$ depth and were done for every meter depth down to $13 \mathrm{~m}$. Night measurements (no moon) were done at horizontal distances between 0.5 and $15.5 \mathrm{~m}$ from the lamp $(0.5 \mathrm{~m}$ intervals) with the light sensor head pointing towards the light source. Light irradiance decreased quickly with distance from the surface (Fig. 3, NL-day) and the different light sources (Fig. 3). Already at $4 \mathrm{~m}$ distance, the irradiance was down to $1 \%$ of the value measured $0.5 \mathrm{~m}$ from both the $\mathrm{MH}$ and LED lamp at full power. Both night and daytime measurements were done outside the experimental cages to avoid interference from the fish. No measureable irradiance was found in the NL cages during the night. The Secchi depth during measurements was $10 \mathrm{~m}$.

During the night of 7 March, the irradiances within a cage holding fish were measured. The measurements were done with $3 \mathrm{~m}$ distance between the lamp and the sensor, at $2 \mathrm{~m}$ depth (with few fish present between lamp and sensor), and at $5 \mathrm{~m}$ depth (depth of highest biomass estimated from the on-line echo sounder. The measurements were done every $15 \mathrm{~s}$ between 21:00 and 22:00 h ( $2 \mathrm{~m}$, few fish) and 23:00 and 00:00 h (5 m, maximum density). During the measurements, the fish positioned themselves evenly from the cage wall towards the cage centre, but avoided the nearest $2 \mathrm{~m}$ around the lamp. Based on the average light irradiance measured over $1 \mathrm{~h}$ (Fig. 4), and an approximately $1 \mathrm{~m}$ broad school of fish between lamp and sensor, at a relevant density for caged farmed salmon, the attenuation of light irradiance by the fish was approximately $50 \%$.

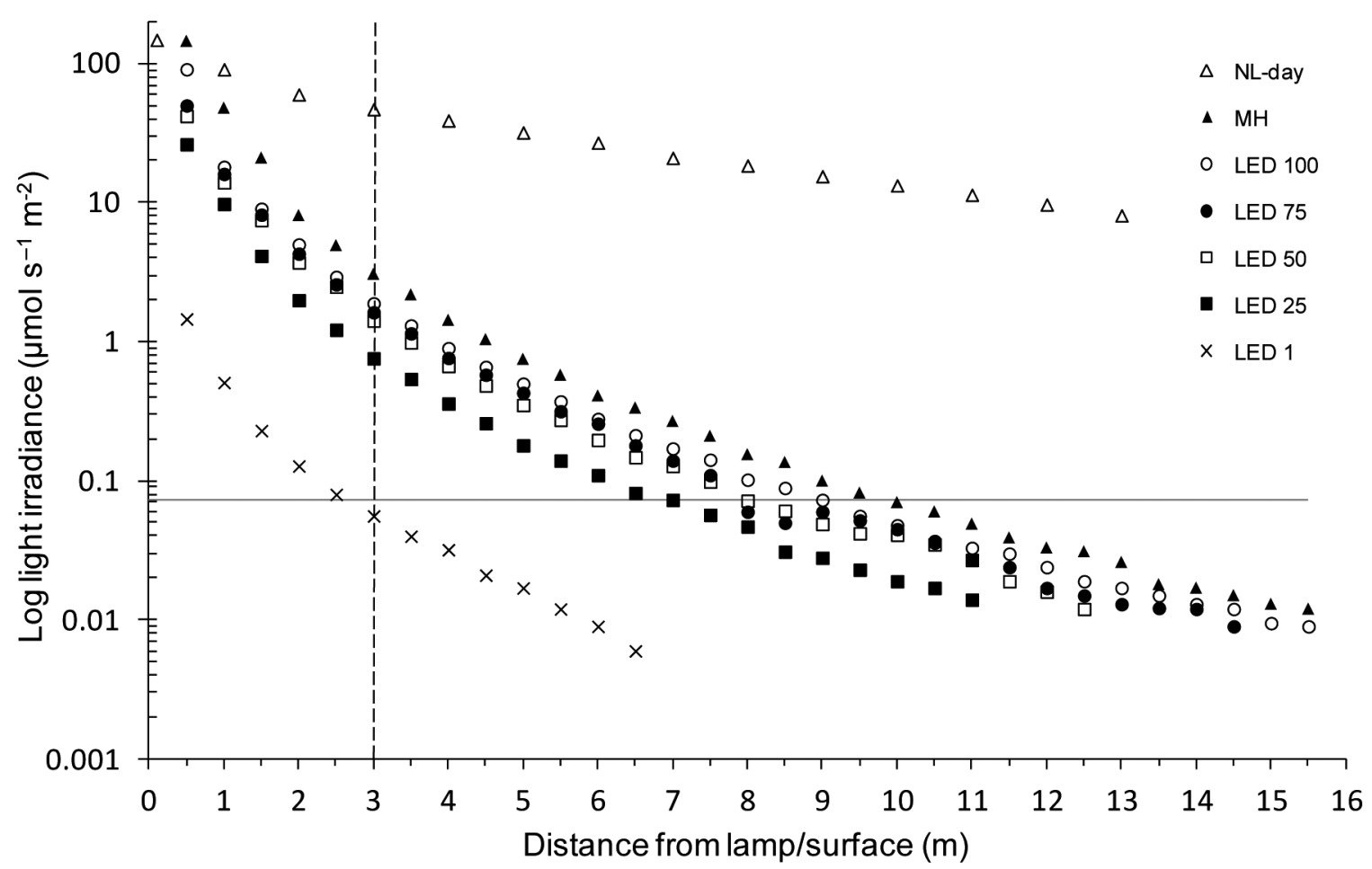

Fig. 3. Horizontal profile of light-attenuation generated by the LED and metal halide (MH) lamps measured on a night with no moon. The light intensity at different depths on a clear day, but with no direct sunlight, is included for comparison (NL-day). The horizontal line is the irradiation necessary to reduce plasma melatonin to daytime levels (see Migaud et al. 2006); the vertical line shows the irradiance values used in the correlation analysis (Fig. 6) 


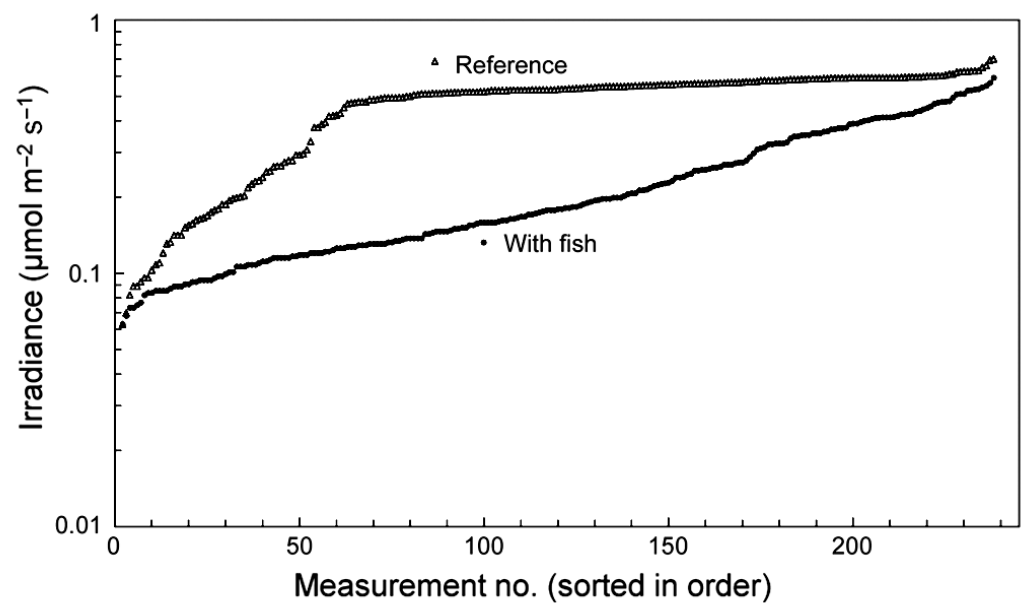

Fig. 4. Light irradiance measured $3 \mathrm{~m}$ from a metal halide lamp at a reference depth in cages ( $2 \mathrm{~m}$ depth with few Atlantic salmon present between lamp and sensor), compared to measurements at the depth of the highest biomass (5 m) with fish between the lamp and the measurement probe. Data were stored every $15 \mathrm{~s}$, sorted and plotted in increasing order. The reference data were collected between 21:00 and 22:00 h (mean $\pm \mathrm{SD} ; 0.47 \pm 0.16 \mu \mathrm{mol} \mathrm{s}^{-1} \mathrm{~m}^{-2}$ ) and data with fish present between 23:00 and 00:00 h $\left(0.23 \pm 0.13 \mu \mathrm{mol} \mathrm{s}^{-1} \mathrm{~m}^{-2}\right)$

\section{Temperature and salinity}

The fish farm where the experiment was done is located $1500 \mathrm{~m}$ from the outlet of a hydroelectric powerplant and has a brackish (<25 ppt) layer between 0 and 2-5 $\mathrm{m}$ (Fig. 5A). The temperature at $5 \mathrm{~m}$ (below the brackish layer) varied between 6 and $8^{\circ} \mathrm{C}$ until March, between 7 and $10^{\circ} \mathrm{C}$ during April and May and between 9 and $12^{\circ} \mathrm{C}$ in June (Fig. 5B).

\section{Calculations and statistics}

Fulton's condition factor $(K)$ was calculated as $100 W / L^{3}$, where $W$ is body weight $(\mathrm{g})$ and $L$ is fork length (cm) (Busacker et al. 1990). The change in $K$
$(\Delta K)$ was calculated as $K_{2}-K_{1}\left(K\right.$ at $t_{2}-K$ at $\left.t_{1}\right)$. Specific growth rate $\left(\mathrm{SGR}, \% \mathrm{~d}^{-1}\right)$ was calculated as $(\exp (q)-1) 100$ (Houde $\&$ Scheckter 1981), where $q=\left[\ln \left(W_{2}\right)-\right.$ $\left.\ln \left(W_{1}\right)\right] /\left(t_{2}-t_{1}\right)$ (Bagenal \& Tesch 1978) and $W_{2}$ and $W_{1}$ are average body weight at times $t_{2}$ and $t_{1}$, respectively. The GSI was calculated using: GSI $=\{$ [gonadal weight (g)100]/body weight (g)\}.

Statistica version 12 (Dell Statistica) was used for statistical analysis and the preparation of graphs. Within sampling points (dates), nested ANOVAs were used to test for significant effects of: (1) treatment (NL, MH and LED100) on weight and SGR with replicate (sea-cage) nested as a random factor in treatment groups; (2) treatment and time of day (day/night) on swimming speed, with replicate nested as a random factor in treatment group and time point. Significant nested ANOVAs were followed by factorial ANOVAs and Newman-Keuls post hoc tests. To reveal possible significant correlations between irradiance and body weight, $K$, SGR and $\Delta K$, Pearson product moment correlations were computed within sampling points. The analysis was done on the LEDilluminated groups to find the effect of LED irradiation and later on all illuminated groups (LED and $\mathrm{MH}$ ) to find the effect of irradiance independent of illumination technique; $\mathrm{p}<0.05$ was regarded as significant. The irradiances $3 \mathrm{~m}$ from the light source (Fig. 3) were used in the correlation analysis, and for the replicated groups (LED100 and MH) the mean value was used. $\chi^{2}$ tests were used to test group differences (NL, MH, LED100) in the incidence of sexually mature males (level of significance Bonferroni adjusted to $\mathrm{p}<0.017$ ).
Fig. 5. (A) Salinity (ppt) and (B) temperature $\left({ }^{\circ} \mathrm{C}\right)$ between 0 and $15 \mathrm{~m}$ depth during the experiment

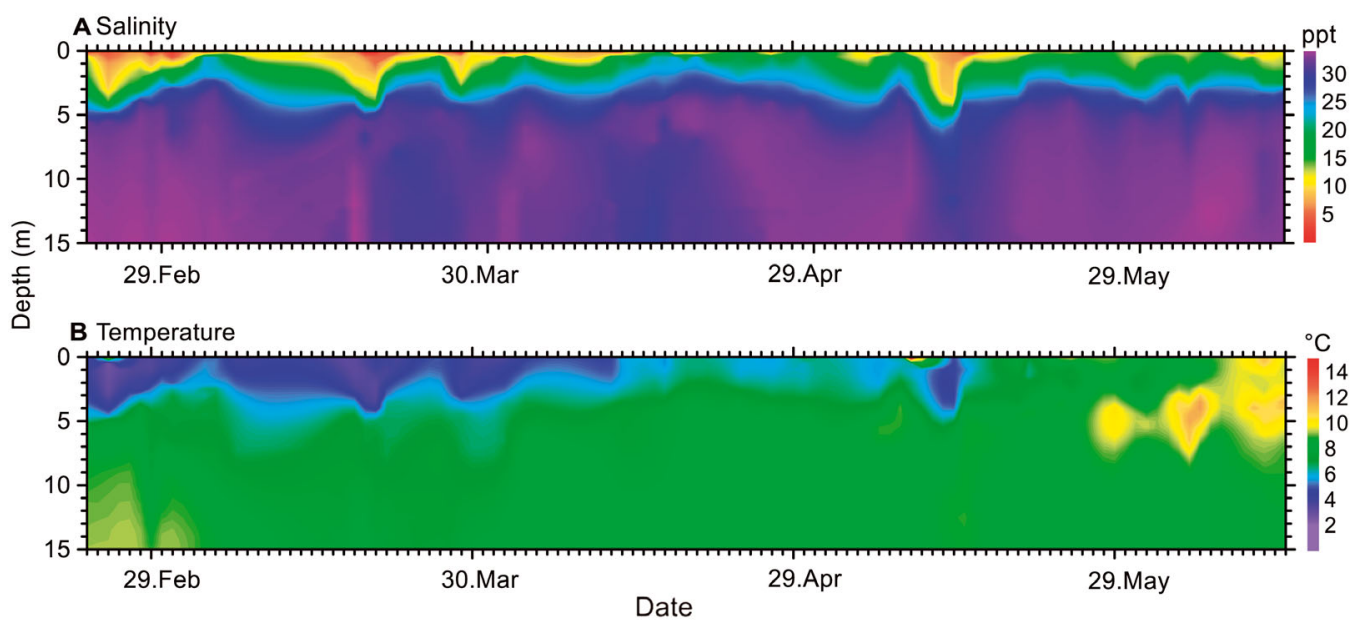




\section{RESULTS}

The Atlantic salmon reared under continuous light for 5 mo from January were heavier and had a higher condition factor than salmon reared under natural light. The growth effect was independent of lighting technology (LED or $\mathrm{MH}$ ) but was dependent on light irradiance; growth rate between April and June was positively correlated with LED irradiance.

\section{Growth and sexual maturation}

Neither photoperiod, lighting technology nor irradiance gave significant effects on weight, SGR, $K$ or $\Delta K$ in the first period (until 13 April) (Table 1, Fig. 6). In the last period, the MH and LED100 groups grew faster than the NL group and were significantly larger and had a significantly higher condition factor in June (Table 1).

In the last period there was a significant correlation between LED irradiance and SGR $\left(p=0.02, r^{2}=0.89\right.$, Fig. 6B) and a close to significant correlation ( $\mathrm{p}=$ 0.07, $\mathrm{r}^{2}=0.73$, Fig. 6D) between LED irradiation and $\Delta K$. In June there was a close to significant correlation between LED irradiance and weight $\left(\mathrm{p}=0.10, \mathrm{r}^{2}\right.$ $=0.65$, Fig. 6A) and $K\left(p=0.08, r^{2}=0.69\right.$, Fig. 6C). If the $\mathrm{MH}$ data were included in the correlation analysis $\left(\mathrm{MH}\right.$ irradiance $\left.=3.06 \mu \mathrm{mol} \mathrm{s}{ }^{-1} \mathrm{~m}^{-2}\right)$, the correla- tions (irrespective of illumination technique) were all significant (weight: $\mathrm{p}=0.03, \mathrm{r}^{2}=0.72 ; K: \mathrm{p}=0.03, \mathrm{r}^{2}=$ 0.75; SGR: $\mathrm{p}=0.01, \mathrm{r}^{2}=0.93 ; \Delta K: \mathrm{p}=0.04, \mathrm{r}^{2}=0.71$ ), and SGR and $\Delta K$ increased with irradiance in the last period and weight and $K$ in June increased with irradiance.

The incidence of sexually mature males was significantly higher in the NL group than in the $\mathrm{MH}$ or LED100 groups (Table 1). A generally low incidence of maturation did not allow for testing the effects of LED irradiance. In females, sexual maturation was only found in 1 of the NL cages (Table 1).

\section{Swimming speed}

Swimming speed ( $V_{\text {day }}$ and $V_{\text {night }}$ ) was only significantly affected by treatment in February (NL, MH and LED100), but with significant effects of time of day (day/night) and with significant interaction between treatment and time of day in all 3 sampled periods. $V_{\text {day }}$ of the NL fish averaged $0.8,0.65$ and $0.63 \mathrm{BL} \mathrm{s}^{-1}$ in February, March and May, respectively, and $V_{\text {night }}$ values were significantly reduced to 25 and $26 \%$ of their respective $V_{\text {day }}$ values in February and March and with a smaller, but significant reduction to $84 \%$ in May (Fig. 7). The $V_{\text {day }}$ of the $\mathrm{MH}$ and LED100 groups was significantly lower than that of the NL group in March, and MH was significantly

Table 1. Mean \pm SD weight and condition factor $(K)$ of Atlantic salmon Salmo salar given for each cage and treatment group in January, April and June, and incidence of sexual maturation (\%) for males (M; mature fish gonadosomatic index, GSI > $0.4 \%$ ) and females $\left(F_{;}\right.$mature fish GSI $\left.>0.5 \%\right)$ for each cage registered at the June sampling. Significant differences within sample dates are noted by different superscript letters. The number of sampled fish per cage varied between 93 and 148 . NL: natural light; LED 1, 25, 50, 100: light-emitting diode lamp dimmed down to a percentage $(1,25,50$ or $100 \%)$ of its maximum output; MH: metal halide lamp

\begin{tabular}{|c|c|c|c|c|c|c|c|c|}
\hline \multirow{2}{*}{$\begin{array}{l}\text { Sample date } \\
\text { Group }\end{array}$} & \multicolumn{2}{|c|}{16 January } & \multicolumn{2}{|c|}{13 April } & \multirow[b]{2}{*}{$\begin{array}{l}\text { Weight } \\
(\mathrm{kg})\end{array}$} & \multirow{2}{*}{$\begin{array}{l}-18 \text { June } \\
K\end{array}$} & \multirow[b]{2}{*}{$\begin{array}{c}\text { Mature } \\
\text { M (\%) }\end{array}$} & \multirow[b]{2}{*}{$\begin{array}{c}\text { Mature } \\
\text { F (\%) }\end{array}$} \\
\hline & $\begin{array}{l}\text { Weight } \\
(\mathrm{kg})\end{array}$ & $K$ & $\begin{array}{l}\text { Weight } \\
\text { (kg) }\end{array}$ & $K$ & & & & \\
\hline NL 1 & $3.02 \pm 0.86$ & $1.14 \pm 0.12$ & $5.44 \pm 1.50$ & $1.31 \pm 0.14$ & $6.64 \pm 1.47$ & $1.29 \pm 0.14$ & 13.7 & 9.8 \\
\hline NL 2 & $3.21 \pm 0.92$ & $1.18 \pm 0.13$ & $5.44 \pm 1.32$ & $1.28 \pm 0.14$ & $6.27 \pm 1.62$ & $1.25 \pm 0.11$ & 2.5 & 0.0 \\
\hline NL 3 & $3.20 \pm 0.90$ & $1.15 \pm 0.10$ & $5.13 \pm 1.17$ & $1.26 \pm 0.13$ & $6.05 \pm 1.30$ & $1.22 \pm 0.11$ & 5.6 & 0.0 \\
\hline LED 1 & $3.10 \pm 0.90$ & $1.15 \pm 0.11$ & $4.98 \pm 1.25$ & $1.27 \pm 0.11$ & $5.99 \pm 1.39$ & $1.24 \pm 0.11$ & 0.0 & 0.0 \\
\hline LED 25 & $3.25 \pm 0.81$ & $1.15 \pm 0.09$ & $5.33 \pm 1.34$ & $1.23 \pm 0.14$ & $6.58 \pm 1.41$ & $1.29 \pm 0.11$ & 6.3 & 0.0 \\
\hline LED 50 & $3.27 \pm 0.91$ & $1.16 \pm 0.13$ & $5.12 \pm 1.46$ & $1.25 \pm 0.11$ & $6.49 \pm 1.74$ & $1.33 \pm 0.14$ & 0.0 & 0.0 \\
\hline LED 75 & $3.23 \pm 0.75$ & $1.16 \pm 0.10$ & $5.00 \pm 1.10$ & $1.22 \pm 0.12$ & $6.47 \pm 1.60$ & $1.28 \pm 0.13$ & 0.0 & 0.0 \\
\hline MH 1 & $3.30 \pm 0.98$ & $1.17 \pm 0.13$ & $4.97 \pm 1.38$ & $1.26 \pm 0.12$ & $6.86 \pm 1.71$ & $1.36 \pm 0.13$ & 0.0 & 0.0 \\
\hline MH 2 & $3.26 \pm 0.92$ & $1.17 \pm 0.14$ & $5.11 \pm 1.39$ & $1.23 \pm 0.12$ & $7.18 \pm 1.40$ & $1.33 \pm 0.09$ & 3.6 & 0.0 \\
\hline MH 3 & $3.28 \pm 0.88$ & $1.17 \pm 0.13$ & $5.33 \pm 1.38$ & $1.26 \pm 0.13$ & $7.33 \pm 1.57$ & $1.35 \pm 0.11$ & 0.0 & 0.0 \\
\hline LED 1001 & $3.29 \pm 0.86$ & $1.19 \pm 0.10$ & $5.36 \pm 1.32$ & $1.28 \pm 0.16$ & $7.07 \pm 1.64$ & $1.33 \pm 0.10$ & 0.0 & 0.0 \\
\hline LED 1002 & $3.44 \pm 0.81$ & $1.20 \pm 0.11$ & $5.23 \pm 1.43$ & $1.26 \pm 0.13$ & $7.27 \pm 1.52$ & $1.33 \pm 0.14$ & 0.0 & 0.0 \\
\hline NL & $3.14^{\mathrm{a}} \pm 0.89$ & $1.16^{\mathrm{a}} \pm 0.01$ & $5.34^{\mathrm{a}} \pm 1.34$ & $1.28^{\mathrm{a}} \pm 0.18$ & $6.32^{\mathrm{a}} \pm 1.51$ & $1.25^{\mathrm{a}} \pm 0.12$ & $6.1^{\mathrm{a}}$ & 3.3 \\
\hline $\mathrm{MH}$ & $3.28^{\mathrm{a}} \pm 0.92$ & $1.17^{\mathrm{a}} \pm 0.01$ & $5.14^{\mathrm{a}} \pm 1.39$ & $1.25^{\mathrm{a}} \pm 0.12$ & $7.12^{\mathrm{b}} \pm 1.57$ & $1.35^{\mathrm{b}} \pm 0.11$ & $1.3^{\mathrm{b}}$ & 0.0 \\
\hline LED100 & $3.37^{a} \pm 0.83$ & $1.19^{\mathrm{a}} \pm 0.01$ & $5.30^{\mathrm{a}} \pm 1.37$ & $1.27^{\mathrm{a}} \pm 0.14$ & $7.16^{\mathrm{b}} \pm 1.58$ & $1.33^{\mathrm{b}} \pm 0.12$ & $0.0^{\mathrm{b}}$ & 0.0 \\
\hline
\end{tabular}




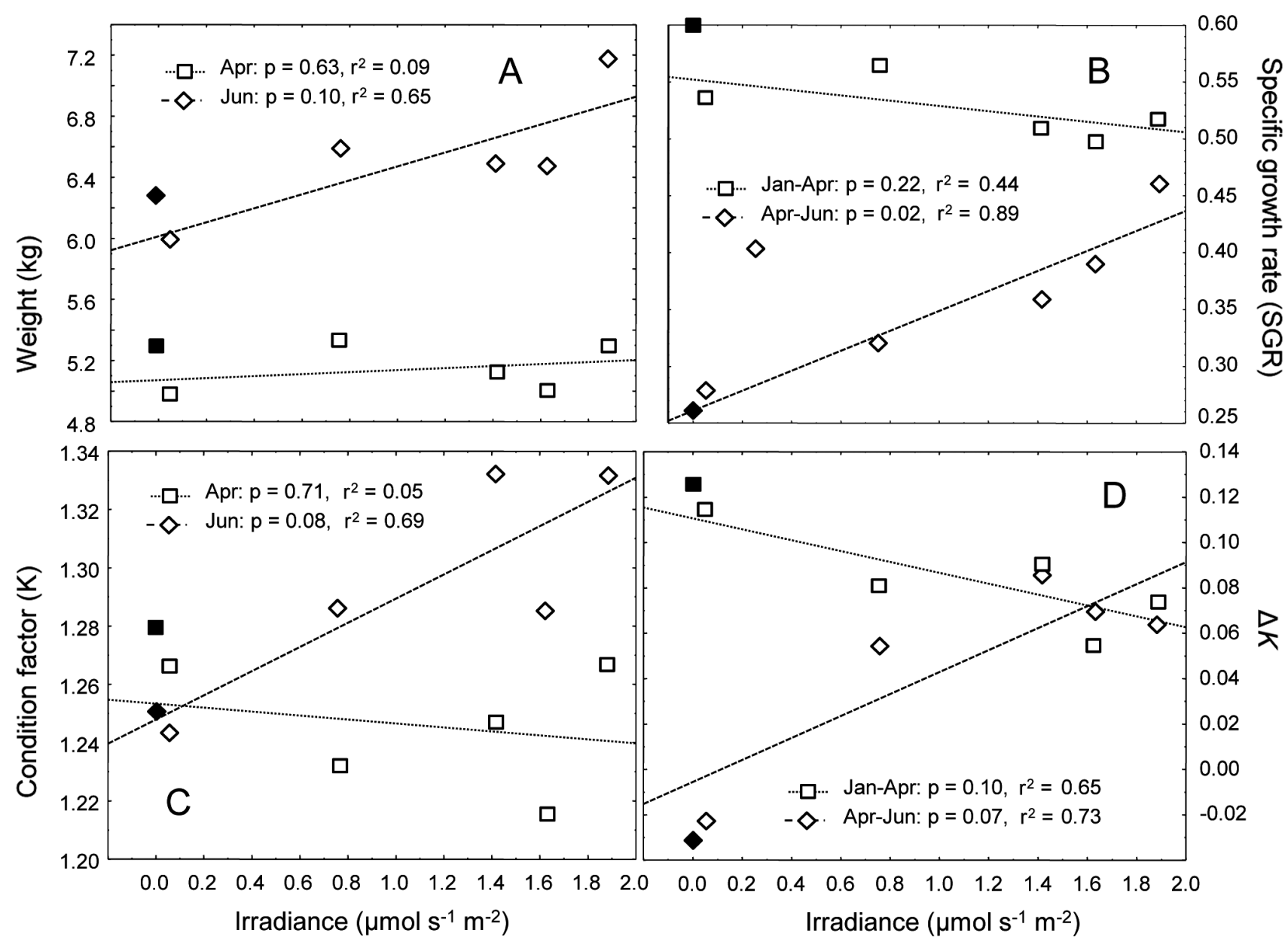

Fig. 6. Correlation between irradiance $3 \mathrm{~m}$ from the LED light sources (vertical line in Fig. 3) and (A) weight, (B) specific growth rate, (C) condition factor $K$ and (D) change in condition factor $(\Delta K)$ of Atlantic salmon Salmo salar. The corresponding values of the natural light (NL) group (black symbols) are included for illustrational purposes, but were not included in the correlation analysis

Fig. 7. Nighttime and daytime average swimming speed (body lengths [BL] $\mathrm{s}^{-1}$ ) of Atlantic salmon Salmo salar in the natural light (NL), metal halide (MH) and maximum-output LED (LED100) groups in February, March and May

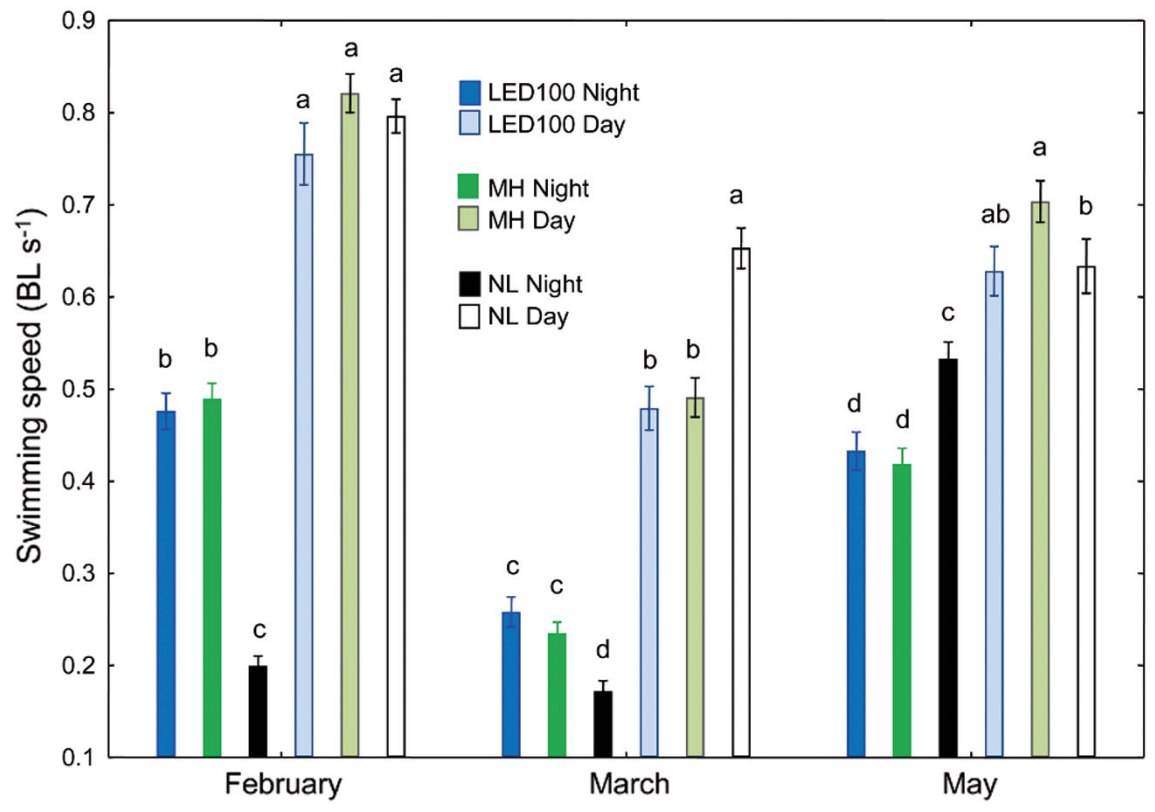


higher than the NL group in May. Also in the MH and LED100 groups, $V_{\text {night }}$ was significantly lower than $V_{\text {day }}$ at all times. However, $V_{\text {night }}$ of $\mathrm{MH}$ and LED100 was significantly higher than NL in February and March and lower in May, and the reduction was only between 48 and $69 \%$ of their $V_{\text {day }}$ values.

\section{DISCUSSION}

This study confirms that highly efficient LED light sources may replace the traditionally used $\mathrm{MH}$ lamps at the same irradiation. Altogether our results are in line with earlier studies showing that continuous artificial light superimposed on the natural light cycle from about winter solstice has a growth-stimulating effect on Atlantic salmon in sea-cages (Kråkenes et al. 1991, Hansen et al. 1992, Oppedal et al. 1997, 2006, Duncan et al. 1999, Endal et al. 2000, Johnston et al. 2003). This growth stimulation is related to the light/extended photoperiod itself, and not to a longer feeding period (Kråkenes et al. 1991, Taylor et al. 2006). Published data indicate that fish growth follows a seasonal pattern influenced by variations in day length (reviewed by Boeuf \& Falcón 2001). Further, the fact that Endal et al. (2000) and Oppedal et al. (2006) found a continuation of faster growth than under natural light, also after artificial lighting ceased, supports the theory of an adjusted circannual growth rhythm. Along the same lines, Oppedal et al. (1997, 1999, 2003, 2006), Nordgarden et al. (2003) and Johnston et al. (2003) found distinct shifts in the seasonal patterns of SGR and condition factor following the onset or switching off of artificial light. In the present study, no differences were found after 3 mo, but the groups that were reared under continuous light were significantly heavier and had a higher condition factor 5 mo after the onset of light, harmonizing with the studies above.

It has also been suggested that growth enhancement under long photoperiods is caused by a direct photo-stimulation of growth (Saunders \& Harmon 1988, Komourdjian et al. 1989). Johnston et al. (2003) compared the muscle growth of salmon reared under continuous and natural light from the start of the first sea winter, and found that continuous light increased muscle fibre recruitment, possibly by overcoming a short day inhibition of myogenic progenitor cell proliferation. These fish had $28.5 \%$ higher fibre number than fish reared under natural light $40 \mathrm{~d}$ after the onset of continuous light. As the rate of hypertrophy was unaffected by the light treatment, fish under continuous light subsequently grew better and reached $30 \%$ higher body weight after mid-summer. A significantly higher condition factor paralleled the growth increase (Johnston et al. 2003). The development of condition factor in the study of Johnston et al. (2003) is very similar to the results of Nordgarden et al. (2003) and Oppedal et al. $(2003,2006)$, but in the latter studies, the fish were followed for an additional 6 mo, an extension that revealed a seasonal pattern.

In the studies above, relatively high-intensity light sources were used, but as shown in the present study, where SGR between April and June increased with increasing LED light irradiance, and in earlier studies on Atlantic salmon (Oppedal et al. 1997) and rainbow trout (Taylor et al. 2006), the growth response to the continuous light can be dependent on the light intensity/irradiance. However, in studies using Atlantic salmon juveniles reared under a simulated natural photoperiod (SNP) (winter and spring), combining darkness with a photophase with different light intensities, Stefansson et al. (1993) found no effect of light intensity (27 to 715 lux) on growth, and Handeland et al. (2013) concluded that a light intensity above 20-40 lux was needed to achieve optimal growth. Similarly, growth was insignificant between salmon fry reared at continuous 1400 lux, continuous 27 lux or a photoregime where a 1400 lux SNP photophase was superimposed on a continuous 27 lux background illumination (Stefansson et al. 1990). In rainbow trout reared under a 16 h light:8 h dark photoperiod (Kwain 1975), growth was reduced under 0.2 lux, but not under 2 or 20 lux. Taken together, these studies indicate that unless the light intensity is so low that it affects the feeding ability (0.03-0.04 lux, see Elliott 2011), growth in salmonids is little affected by light intensity. However, studies wherein continuous light was superimposed on the natural light in cages or tanks found a positive correlation between growth and the irradiance of the superimposed light in Atlantic salmon (Oppedal et al. 1997) and rainbow trout (Taylor et al. 2006).

In vertebrates, the pineal gland produces melatonin (described as a biological time-keeping hormone) at night, resulting in high levels in the plasma and cerebrospinal fluid during the night and low levels during the day (reviewed by Mayer et al. 1997, Falcón et al. 2010, Migaud et al. 2010). Moreover, differential results between ex vivo pineal production and in vivo melatonin studies in salmon indicate that retinal and deep brain photoreception may also contribute to the control of melatonin production by the pineal gland (Migaud et al. 2006). In some species, this rhythm is under endogenous control, but in salmonids, melatonin production seems to be under 
photoperiod control only (Falcón et al. 2007), and the circulating melatonin levels reflect the light-dark regime accurately (Alvariño et al. 1993, Randall et al. 1995).

The ability of the light environment to suppress this rhythmic melatonin production is often used as an indication of its success, and Porter et al. (2000) proposed a model where the 'dark' phase melatonin must be reduced below a threshold level to alter growth and sexual maturation. Later, Migaud et al. (2006) indicated $0.016 \mathrm{~W} \mathrm{~m}^{-2}\left(0.074 \mu \mathrm{mol} \mathrm{s}^{-1} \mathrm{~m}^{-2}\right)$ as a threshold, where higher irradiances give melatonin levels comparable to daytime levels, and Leclercq et al. (2011) found a maximum suppression of sexual maturation when nighttime mean irradiance was kept above $0.012 \mathrm{~W} \mathrm{~m}^{-2}\left(0.056 \mu \mathrm{mol} \mathrm{s}^{-1} \mathrm{~m}^{-2}\right)$. However, in a study on Atlantic cod Gadus morhua pineal gland, Vera et al. (2010) found that the intensity threshold was dependent on the light intensity in the previously experienced 'day', an idea that also has been suggested for Atlantic salmon (Oppedal et al. (1997) and rainbow trout (Taylor et al. 2006). In a cage farm like in our study, artificial light is superimposed on the natural light, which increases in period and irradiance during late winter and spring (Fig. 8). If the irradiance from the artificial light source is high

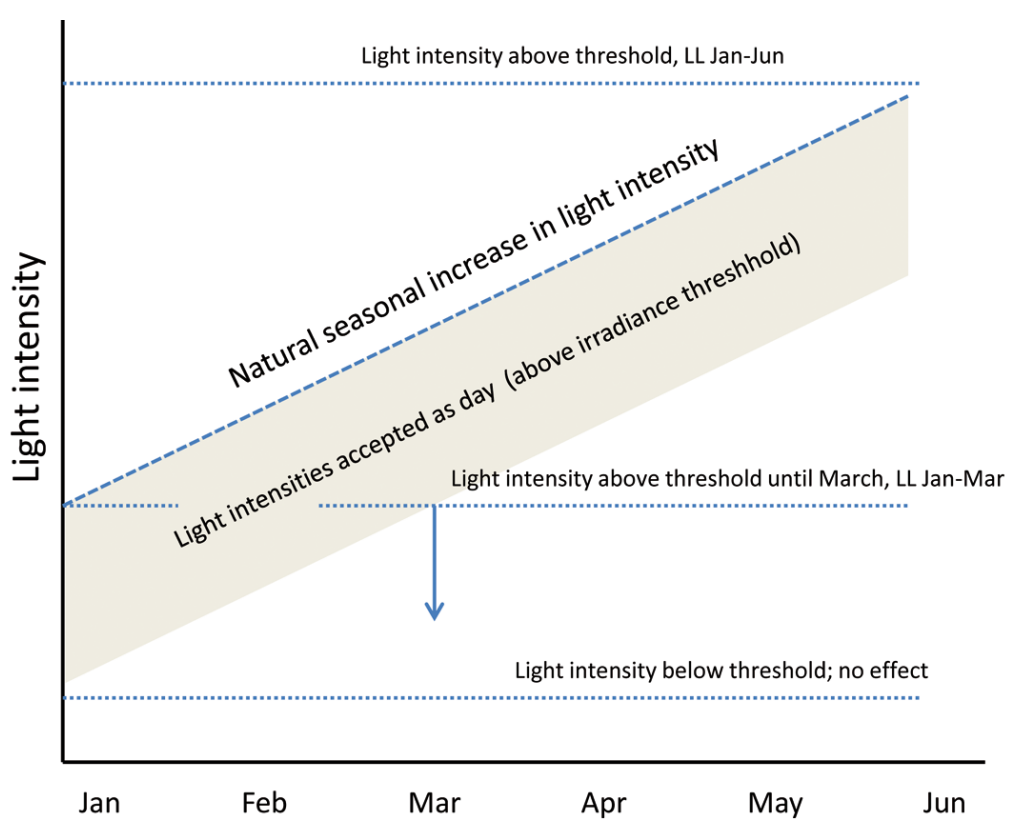

Fig. 8. Possible model for how artificial light of different intensities can translate into a periodic continuous light effect. Natural light increases in period and irradiance during late winter and spring. If the irradiance from the artificial light source is high enough, it will give a long day signal throughout late winter and spring, while irradiances that remain below the threshold will not be experienced as different from the natural light. A light source at intermediate irradiation will give a long day signal until it is outcompeted by the natural light. LL: continuous artificial light enough, it will give a long day signal throughout late winter and spring, and an irradiance that is below the threshold at all times will not be perceived as different from the natural light. Indeed, seen from the present correlation between changes in condition factor and SGR, the fish receiving the lowest LED irradiation developed equally and had a comparable swimming speed (see below) as the fish under natural light. A light source giving an intermediate irradiation will, however, give a long day signal until it is outcompeted by the natural light. It is therefore possible that an intermediate light irradiance will give a long day signal for a shorter period of time and be more comparable to Endal et al. (2000) where continuous light for shorter periods in between November and July gave an intermediate growth stimulation compared to continuous light throughout, and natural light.

\section{Swimming activity}

The main effect of the continuous light was to increase the nighttime swimming activity $\left(V_{\text {night }}\right)$ during the winter and early spring in accordance with Oppedal et al. (2001) and in contrast to the high $V_{\text {day }}$ and low $V_{\text {night }}$ of the NL fish (earlier described by Juell \& Westerberg (1993), Juell (1995) and Oppedal et al. (2001). This diel rhythm in swimming speed under natural light has been related to light level and might reflect a natural activity rhythm or a loss of ability to school below a critical light level (Juell 1995). Also the increase in $V_{\text {night }}$ in the NL group during late spring and early summer has been observed by Oppedal et al. (2001).

It is generally assumed that exercise training up to speeds of $1.5 \mathrm{BL} \mathrm{s}^{-1}$ improves growth rates and food conversions in many species of fish (see review by Davison 1997). Thus, it is possible that the increased $V_{\text {night }}$ of the illuminated groups could be a factor contributing to their increased growth rate. However, Kiessling et al. (1994) found no difference in growth between Chinook salmon Oncorhynchus tshawytscha reared at water currents of 0.5 and $1.0 \mathrm{BL} \mathrm{s}^{-1}$, and Solstorm et al. (2015) found no difference in growth between Atlantic salmon reared at 0.2 or $0.8 \mathrm{BL} \mathrm{s}^{-1}$. Thus, no differences in growth were found between salmonids 
swimming at speeds comparable to those observed in the present study $\left(0.2-0.9 \mathrm{BL} \mathrm{s}^{-1}\right)$. Moreover, similar growth differences are found between salmon that are reared under continuous light and natural photoperiod (Nordgarden et al. 2003, Oppedal et al. 2003) when the fish are swimming against the current in tanks. This indicates that the difference in swimming activity is of minor importance for the growth effects seen in the present study.

It is more important that the swimming activity will increase the light exposure of each individual. Light irradiance decreased quickly with distance from the different light sources and was attenuated by at least $50 \%$ by the other fish when measured at a fixed point. However, when the fading natural light is weaker than the artificial light, the salmon will move towards the light to retain schooling behavior (Juell et al. 2003). This photic attraction (see Juell et al. 2003, Oppedal et al. 2007, Stien et al. 2014, Wright et al. 2015) and swimming activity (Oppedal et al. 2001, present study) will level out the light exposure between individuals and increase the average irradiance compared with the levels measured at a fixed point.

\section{Sexual maturation}

The reduced incidence of sexual maturation in the LL groups in the present study concur with an earlier study on 2SW salmon (Taranger et al. 1998), and studies on grilse maturation (1SW) in springtransferred (Taranger et al. 1995, Oppedal et al. 1997, Porter et al. 1999, Leclercq et al. 2011), and autumntransferred (Oppedal et al. 2006) salmon. The reduction in the incidence of sexual maturation was also independent of lighting technology, in line with Leclercq et al. (2011), who suggested that light irradiance rather than light technology or light spectral composition was the prime parameter reducing the incidence of sexual maturation. However, in the present study, the overall incidence of sexual maturation was very low and the data did not allow for testing of the effect of light intensity on incidence of sexual maturation. However, if we compare our measured irradiances with the threshold value of Migaud et al. (2006), this was reached $9.5 \mathrm{~m}$ and $9.0 \mathrm{~m}$ from the $\mathrm{MH}$ and LED100 light sources and corresponding values for the dimmed LED lamps were $8 \mathrm{~m}$ (LED75), $7.8 \mathrm{~m}$ (LED50), $7 \mathrm{~m}$ (LED25) and $2.5 \mathrm{~m}$ (LED1). This means that the full volume of all LL cages except LED1 had irradiations above the theoretical threshold level. This effective volume is reduced by the attenuation of the fish, but this is again counteracted by their swim- ming activity, which brings them close enough to the lamps often enough to make the irradiation in all LL cages high enough to reduce the incidence of sexual maturation.

\section{CONCLUSIONS}

The present study confirms that high intensity light superimposed on natural light from January to June in salmon cage farming increases growth, reduces the incidence of sexual maturation and allows the salmon to swim during the night. LED lamps may replace $\mathrm{MH}$ at similar intensity, as light irradiance was more important than the lamp type. Reducing the light irradiance of the superimposed light reduced the growth-stimulating effect, but all irradiances reduced the incidence of sexual maturation. We suggest that the salmon interpret a light regime composed of artificial light superimposed on a natural light environment as a long day until the artificial light is outcompeted by the natural light. The consequence of this hypothesis would be that the natural light, which increases in period and irradiance during late winter and spring, will turn off a long day signal and that intermediate irradiances will have the same effect as a shorter period of higher intensity continuous light.

Acknowledgements. We thank the staff at Matre Research station for rearing of fish and all technical assistance; Kristian Dahle and Jan Olav Fosse for tending the fish, Jan Erik Fosseidengen for instrument and light setup and Einar ByeIngebrigtsen for spectral irradiance measurements. The work was funded by the Norwegian Research Council Centre for Research-Based Innovation in Aquaculture Technology (CREATE) and industrial partners therein.

\section{LITERATURE CITED}

Alvariño JMR, Randall CF, Bromage NR (1993) Effects of skeleton photoperiods on melatonin secretion in the rainbow trout, Oncorhynchus mykiss (Walbaum). Aquacult Fish Manag 24:157-162

Bagenal TB, Tesch FW (1978) Age and growth. Methods for assessment of fish production in fresh waters. In: Bagenal T (ed) IBP handbook no. 3, 3rd edn. Blackwell, Oxford, p 101-136

Björnsson BT (1997) The biology of salmon growth hormone: from daylight to dominance. Fish Physiol Biochem 17: 9-24

Boeuf G, Falcón J (2001) Photoperiod and growth in fish. Vie Milieu 51:247-266

Bromage N, Porter M, Randall C (2001) The environmental regulation of maturation in farmed finfish with special reference to the role of photoperiod and melatonin. Aquaculture 197:63-98 
Busacker GP, Adelman IR, Goolish EM (1990) Growth. In: Schreck CB, Moyle PB (eds) Methods for fish biology. American Fisheries Society, Bethesda, MD, p 363-387

* Davison W (1997) The effects of exercise training on teleost fish, a review of recent literature. Comp Biochem Physiol A Physiol 117:67-75

* Duncan N, Michell D, Bromage N (1999) Post-smolt growth and maturation of out-of-season 0+ Atlantic salmon (Salmo salar) reared under different photoperiods. Aquaculture 177:61-71

Duston J, Bromage N (1988) The entrainment and gating of the endogenous circannual rhythm of reproduction in the female rainbow trout (Salmo gairdneri). J Comp Physiol A Neuroethol Sens Neural Behav Physiol 164: 259-268

Elliott JM (2011) A comparative study of the relationship between light intensity and feeding ability in brown trout (Salmo trutta) and Arctic charr (Salvelinus alpinus). Freshw Biol 56:1962-1972

Endal HP, Taranger GL, Stefansson SO, Hansen T (2000) Effects of continuous additional light on growth and sexual maturity in Atlantic salmon, Salmo salar, reared in sea cages. Aquaculture 191:337-349

Falcón J, Besseau L, Sauzet S, Boeuf G (2007) Melatonin effects on the hypothalamo-pituitary axis in fish. Trends Endocrinol Metab 18:81-88

Falcón J, Migaud H, Muñoz-Cueto JA, Carrillo M (2010) Current knowledge on the melatonin system in teleost fish. Gen Comp Endocrinol 165:469-482

Handeland SO, Imsland AK, Ebbeson LOE, Nilsen TO and others (2013) Low light intensity can reduce Atlantic salmon smolt quality. Aquaculture 384-387:19-24

Hansen T, Stefansson SO, Taranger GL (1992) Growth and sexual maturation in Atlantic salmon, Salmo salar L., reared in sea cages at two different light regimes. Aquacult Fish Manag 23:275-280

Houde ED, Scheckter RC (1981) Growth rates, rations and cohort consumption of marine fish larvae in relation to prey concentration. Rapp P-V Reùn Cons Int Explor Mer 178:441-453

Johnston IA, Manthri S, Smart A, Campbell P, Nickell D, Alderson R (2003) Plasticity of muscle fibre number in seawater stages of Atlantic salmon in response to photoperiod manipulation. J Exp Biol 206:3425-3435

Juell JE (1995) The behaviour of Atlantic salmon in relation to efficient cage-rearing. Rev Fish Biol Fish 5:320-335

Juell JE, Westerberg H (1993) An ultrasonic telemetric system for automatic positioning of individual fish used to track Atlantic salmon (Salmo salar L.) in a sea cage. Aquacult Eng 12:1-18

Juell JE, Oppedal F, Boxaspen K, Taranger GL (2003) Submerged light increases swimming depth and reduces fish density of Atlantic salmon Salmo salar L. in production cages. Aquacult Res 34:469-477

Kiessling A, Higgs DA, Dosanjh BS, Eales JG (1994) Influence of sustained exercise at two ration levels on growth and thyroid function of all-female chinook salmon (Oncorhynchus tshawytscha) in seawater. Can J Fish Aquat Sci 51:1975-1984

Komourdjian MP, Fenwick JC, Saunders RL (1989) Endocrinemediated photostimulation of growth in Atlantic salmon. Can J Zool 67:1505-1509

Korsøen ØJ, Dempster T, Fjelldal PG, Oppedal F, Kristiansen TS (2009) Long-term culture of Atlantic salmon (Salmo salar L.) in submerged cages during winter affects behaviour, growth and condition. Aquaculture 296:373-381

KKråkenes R, Hansen T, Stefansson SO, Taranger GL (1991) Continuous light increases growth rate of Atlantic salmon Salmo salar in sea cages. Aquaculture 95:281-287

Kwain WH (1975) Embryonic development, early growth, and meristic variation in rainbow trout (Salmo gairdneri) exposed to combinations of light intensity and temperature. J Fish Res Board Can 32:397-402

Leclercq E, Taylor JF, Sprague M, Migaud H (2011) The potential of alternative lighting-systems to suppress preharvest sexual maturation of 1+ Atlantic salmon (Salmo salar) post-smolts reared in commercial sea-cages. Aquacult Eng 44:35-47

* Mayer I, Bornestaf C, Borg B (1997) Melatonin in nonmammalian vertebrates: physiological role in reproduction. Comp Biochem Physiol A Physiol 118:515-531

*Migaud H, Taylor JF, Taranger GL, Davie A and others (2006) Pineal gland sensitivity to light in salmon (Salmo salar) and sea bass (Dicentrarchus labrax): an in vivo and ex vivo study. J Pineal Res 41:42-52

* Migaud H, Cowan M, Taylor J, Ferguson HW (2007) The effect of spectral composition and light intensity on melatonin, stress and retinal damage in post-smolt Atlantic salmon, Salmo salar. Aquaculture 270:390-404

Migaud H, Davie A, Taylor JF (2010) Current knowledge on the photoneuroendocrine regulation of reproduction in temperate fish species. J Fish Biol 76:27-68

* Nordgarden U, Oppedal F, Taranger GL, Hemre GI, Hansen $T$ (2003) Seasonal changing metabolism in Atlantic salmon (Salmo salar L.) I - Growth and feed conversion ratio. Aquacult Nutr 9:287-293

\% Oppedal F, Taranger GL, Juell JE, Fosseidengen JE, Hansen $\mathrm{T}$ (1997) Light intensity affects growth and sexual maturation of Atlantic salmon (Salmo salar) postsmolts in sea cages. Aquat Living Resour 10:351-357

Oppedal F, Taranger GL, Juell JE, Hansen T (1999) Growth, osmoregulation and sexual maturation of underyearling Atlantic salmon smolt (Salmo salar L.) exposed to different intensities of continuous light in sea cages. Aquacult Res 30:491-499

\% Oppedal F, Juell JE, Taranger GL, Hansen T (2001) Artificial light and season affects vertical distribution and swimming behaviour of post-smolt Atlantic salmon in sea cages. J Fish Biol 58:1570-1584

Oppedal F, Taranger GL, Hansen T (2003) Growth performance and sexual maturation in diploid and triploid Atlantic salmon (Salmo salar L.) in seawater tanks exposed to continuous light or simulated natural photoperiod. Aquaculture 215:145-162

\% Oppedal F, Berg A, Olsen RE, Taranger GL, Hansen T (2006) Photoperiod in seawater influence seasonal growth and chemical composition in autumn sea-transferred Atlantic salmon (Salmo salar L.) given two vaccines. Aquaculture 254:396-410

*oppedal F, Juell JE, Johansson D (2007) Thermo- and photoregulatory swimming behaviour of caged Atlantic salmon: implications for photoperiod management and fish welfare. Aquaculture 265:70-81

* Oppedal F, Vågseth T, Dempster T, Juell JE, Johansson D (2011) Fluctuating sea-cage environments modify the effects of stocking densities on production and welfare parameters of Atlantic salmon (Salmo salar L.). Aquaculture 315:361-368

* Porter MJR, Duncan NJ, Mitchell D, Bromage NR (1999) 
The use of cage lighting to reduce plasma melatonin in Atlantic salmon (Salmo salar) and its effects on the inhibition of grilsing. Aquaculture 176:237-244

Porter MJR, Duncan NJ, Rød AJ, Oppedal F, Taranger GL, Bromage NR (2000) Differential effects of light intensity on growth, maturation and plasma melatonin in Atlantic salmon and its importance in aquaculture. In: Norberg B, Kjesbu OS, Taranger GL, Andersson E, Stefansson SO (eds) Proc 6th Int Symp on the reproductive physiology of fish, 4-9 July 1999, Bergen, Norway. Dept of Fisheries and Marine Biology, University of Bergen, p 321-324

Randall CF, Bromage NR, Thorpe JE, Miles MS, Muir JS (1995) Melatonin rhythms in Atlantic salmon (Salmo salar) maintained under natural and out-of-phase photoperiods. Gen Comp Endocrinol 98:73-86

Saunders RL, Harmon PR (1988) Extended daylength increases postsmolt growth of Atlantic salmon. World Aquacult 19:72-73

Solstorm F, Solstorm D, Oppedal F, Fernö A, Fraser TWK, Olsen RE (2015) Fast water currents reduce production performance of post-smolt Atlantic salmon Salmo salar. Aquacult Environ Interact 7:125-134

* Stefansson SO, Nortvedt R, Hansen TJ, Taranger GL (1990) First feeding of Atlantic salmon, Salmo salar L., under different photoperiods and light intensities. Aquacult Fish Manag 21:435-441

Stefansson SO, Hansen TJ, Taranger GL (1993) Growth and parr-smolt transformation of Atlantic salmon (Salmo salar L.) under different light intensities and subsequent survival and growth in seawater. Aquacult Eng 12:231-243

Editorial responsibility: Chris Noble, Tromsø, Norway
Stien L, Fosseidengen JE, Malm M, Sveier H, Torgersen T, Wright DW, Oppedal F (2014) Low intensity light of different colours modifies Atlantic salmon depth use. Aquacult Eng 62:42-48

Taranger GL, Daae H, Jørgensen KO, Hansen T (1995) Effects of continuous light on growth and sexual maturation in sea water reared Atlantic salmon. In: Goetz F, Thomas P (eds) Proc 5th Int Symp on the reproductive physiology of fish, 2-8 July 1995, Austin, TX, USA. University of Texas, Austin, TX, p 200

*Taranger GL, Haux C, Stefansson SO, Björnsson BTh, Walther BT, Hansen T (1998) Abrupt changes in photoperiod affect age at maturity, timing of ovulation and plasma testosterone and oestradiol-17 $\beta$ profiles in Atlantic salmon, Salmo salar. Aquaculture 162:85-98

* Taranger GL, Carrillo M, Schulz RW, Fontaine P and others (2010) Control of puberty in farmed fish. Gen Comp Endocrinol 165:483-515

Taylor JF, North BP, Porter MJR, Bromage NR, Migaud H (2006) Photoperiod can be used to enhance growth rate and improve feeding efficiency in farmed rainbow trout, Oncorhynchus mykiss. Aquaculture 256:216-234

Vera LM, Davie JF, Taylor JF, Migaud H (2010) Differential light intensity and spectral sensitivities of Atlantic salmon, European sea bass and Atlantic cod pineal glands ex vivo. Gen Comp Endocrinol 165:25-33

*Wright DW, Glaropoulos A, Solstorm D, Stien LH, Oppedal F (2015) Atlantic salmon Salmo salar instantaneously follow vertical light movements in sea cages. Aquacult Environ Interact 7:61-65

Submitted: January 5, 2017; Accepted: April 21, 2017 Proofs received from author(s): June 12, 2017 